\title{
KADAR GLUKOSA DARAH MENCIT (MUS MUSCULUS) DIABETES MELLITUS PASKA PEMBERIAN MODEL LATIHAN ISOMETRIK
}

\author{
Sonia Hadiyanti*, Harmayetty**, Ika Yuni Widyawati** \\ *Mahasiswa Program Studi Ilmu Keperawatan, Fakultas Keperawatan Universitas Airlangga \\ ** Staf Pengajar Fakultas Keperawatan Universitas Airlangga \\ Email: sonia_hadiyanti@yahoo.com
}

\begin{abstract}
Introduction: Based on the latest research, exercise had significant effect to decrease blood glucose. The aimed of this study was to investigate the effect of isometric exercise model on blood glucose in Diabetic Mice (Mus musculus). Methodes: This research was used a true experimental study with randomize post-test only control group design. The sample was male mice (Mus musculus) in 20-27 grams weight. 27 male mice were divided into three groups; the first group was normal group (control) that injected by $\mathrm{NaCl}$ as placebo, the second group was diabetic mice and the third group was diabetic mice with exercise. Both second group and third group were injected by streptozotocin (STZ) to induce Diabetes Mellitus. After 2x24 hours injected, all groups were given oral glucose (Dextrose-40\% or D40). One hour after they given by D40, the third group was treated by isometric exercise used treadmill for 23.31 minutes with $21 \mathrm{~cm} / \mathrm{second}$ speed and $0^{\circ}$ elevation angle. Then the blood samples of all groups were taken to measure the blood glucose level. Data were analyzed by One Kolmogorov-Smirnov test, ANOVA test, and Least Significance Difference (LSD) with significance level of $\alpha<0.05$. Result: The result of One Kolmogorov-Smirnov test showed that there was $p=0.94$ in normal group, $p=0.50$ in diabetic group, and $p=0.19$ in diabetic with exercise group. The result of ANOVA test was $p=0.08$. The result of LSD for blood glucose revealed was $p=0.23$ for diabetic group and diabetic with exercise group. The researcher had an assumption that probably it happened because of in second group there were two mice that had normal blood glucose levels and in the third group the initial blood glucose levels were unknown, hence they probably could had normal blood glucose levels too. Discussion: It can be concluded that there is no effect of isometric exercise to decrease blood glucose. Further research should investigate more about the frequency and intensity of isometric exercise that could has effect to decrease blood glucose.
\end{abstract}

Keywords: Isometric exercise, blood glucose level, Diabetes mellitus, mice

\section{PENDAHULUAN}

Diabetes Mellitus (DM) merupakan suatu kelompok penyakit metabolik dengan karakteristik hiperglikemia yang terjadi karena kelainan sekresi insulin, kerja insulin atau keduanya (American Diabetes Association, 2010). Pada kondisi hiperglikemia, transportasi glukosa yang melintas pada membran sel berkurang dan pembentukan glikogen dari glukosa (glukoneogenesis) berkurang namun tetap terdapat kelebihan glukosa dalam darah (Long, 1996). Kadar glukosa darah penderita DM berada pada level yang melebihi batas normal yaitu $\geq 126 \mathrm{mg} / \mathrm{dl}$ untuk kadar glukosa darah puasa dan $\geq 200 \mathrm{mg} / \mathrm{dl}$ untuk kadar glukosa darah acak (American Diabetes Association, 2011). Hiperglikemia dalam jangka waktu yang lama dapat mengakibatkan kerusakan pada pembuluh darah yaitu pembuluh darah menjadi menyempit sehingga terjadi kerusakan organ seperti gagal ginjal, retinopati diabetik dan kaki diabetes yang merupakan akibat dari jejas pembuluh darah dan saraf, penyakit jantung koroner, hingga serangan stroke (PERKENI, 2011).

Menurut data WHO pada tahun 2000 jumlah pasien DM di dunia (diatas umur 20 
tahun) berjumlah 150 juta orang dengan perkiraan pada tahun 2025 akan menjadi 300 juta orang. International Diabetic Federation (IDF) tahun 2007, mengestimasi bahwa jumlah penduduk Indonesia usia 20 tahun ke atas menderita DM sebanyak 5,6 juta orang pada tahun 2001 dan angka tersebut akan meningkat menjadi 8,2 juta pada tahun 2020 . Ancaman DM terus membayangi kehidupan masyarakat. Sekitar $12-20 \%$ penduduk dunia diperkirakan mengidap penyakit ini dan setiap 10 detik di dunia orang meninggal akibat komplikasi yang ditimbulkan. Komplikasi diabetes terjadi pada semua organ dalam tubuh yang dialiri pembuluh darah kecil dan besar dengan penyebab kematian $50 \%$ akibat penyakit jantung koroner dan 30\% akibat gagal ginjal. Selain kematian, DM juga menyebabkan kecacatan. Sebanyak $30 \%$ penderita DM mengalami kebutaan akibat komplikasi retinopati dan $10 \%$ harus menjalani amputasi tungkai kaki.

Pengelolaan DM terdiri dari 5 pilar utama yaitu perencanaan diet, latihan jasmani, terapi medis, edukasi dan pemantauan gula darah (Smeltzer \& Bare, 2008). Hasil penelitian yang dilakukan oleh Nadimin (2009) menunjukan bahwa diet tinggi serat dapat menurunkan kadar glukosa darah sewaktu (GDS) sebanyak $107 \mathrm{mg} / \mathrm{dl}$, dari $344 \mathrm{mg} / \mathrm{dl}$ menjadi $237 \mathrm{mg} / \mathrm{dl}$ dan pada glukosa darah puasa menurunkan $82,8 \mathrm{mg} / \mathrm{dl}$ dari kadar glukosa puasa awal 225,7 mg/dl menjadi 142,9 mg/dl. Terapi dengan pioglitazone juga secara bermakna menurunkan kadar glukosa darah puasa sebesar $11,7 \mathrm{mg} / \mathrm{dl}$ dan glukosa darah 2 jam post prandial menurun sebesar $30,5 \mathrm{mg} / \mathrm{dl}$ (DeFronzo, 2010). Penelitian lain menunjukkan bahwa latihan fisik senam aerobik dapat menurunkan kadar glukosa darah rerata $235 \mathrm{mg} / \mathrm{dl}$ menjadi $223,14 \mathrm{mg} / \mathrm{dl}$ (Indriyani, 2007). Berdasarkan hasil penelitian yang dilakukan Yoga (2011) bahwa diet, latihan fisik dan terapi farmakologis memiliki efek dalam menurunkan kadar glukosa darah, oleh sebab itu ketiganya tidak dapat dipisahkan satu sama lain dalam pengelolaan DM.

Menurut Soegondo dalam Indriyani (2007) latihan fisik pada penderita DM memiliki peranan yang sangat penting dalam mengendalikan kadar gula dalam darah, dimana saat melakukan latihan fisik terjadi peningkatan pemakaian glukosa oleh otot yang aktif sehingga secara langsung dapat menyebabkan penurunan glukosa darah. Latihan fisik juga dapat menurunkan berat badan, meningkatkan fungsi kardiovaskuler dan respirasi, menurunkan Low Density Lipoprotein (LDL) dan meningkatkan High Density Lipoprotein (HDL) sehingga mencegah penyakit jantung koroner apabila latihan fisik ini secara benar dan teratur. Latihan fisik adalah stimulus yang kuat terhadap masuknya glukosa ke dalam otot skeletal. Sejauh ini penelitian tentang pengaruh latihan terhadap kadar glukosa darah telah dilakukan, namun sampai saat ini model latihan isometrik yang dapat digunakan sebagai metode terapi DM untuk membantu meregulasi kadar glukosa darah belum dapat dijelaskan.

Pada penderita DM mengalami resistensi insulin atau defisiensi insulin yang diakibatkan oleh kerusakan sel $\beta$ pankreas. Kekurangan insulin dapat menyebabkan terjadinya sedikit atau tidak ada ikatan dengan reseptor sehingga proses translokasi transporter glukosa (GLUT-4) ke membran sel menjadi terhambat. GLUT-4 memfasilitasi masuknya glukosa ke dalam sel. Bila proses translokasi GLUT-4 terganggu akan menyebabkan ambilan glukosa dalam darah menjadi terganggu, sehingga terjadi penumpukan glukosa di ekstrasel yang akan mengakibatkan glukosa darah meningkat atau disebut juga hiperglikemia (Ganong, 2008). Latihan fisik akan meningkatkan transportasi glukosa dengan cara menstimulasi translokasi GLUT4 ke permukaan sel otot. Pada saat kontraksi terjadi peningkatan pemakaian energi sehingga terjadi penurunan Adenosine Triphosphate (ATP). ATP akan dipecah menjadi cyclic Adenosine Monophosphate (cAMP) oleh enzim Adenosine Monophosphate Kinase (AMPK), hal ini menyebabkan perubahan metabolik termasuk transport glukosa (Sigal, 2004). Kontraksi otot pada latihan isometrik akan mengakibatkan peningkatan kalsium $\left(\mathrm{Ca}^{2+}\right)$ di sitosol yang akan mengaktifkan enzim Calmodulin Dependent Protein Kinase (CaMK II). Enzim CaMK II dan AMPK akan menstimulasi translokasi GLUT-4 ke permukaan membran sel yang selanjutnya akan membawa glukosa masuk ke dalam sel dan terjadi penurunan glukosa darah (Rose, 2005). 
Berdasarkan uraian diatas, peneliti ingin meneliti pengaruh model latihan isometrik terhadap kadar glukosa darah pada mencit yang dikondisikan mengalami diabtaes mellitus. Kontraksi otot isomerik adalah suatu kontraksi otot dimana tidak terjadi perubahan panjang otot dengan beban dapat berubah-ubah (Marieb, 2007). Latihan isometrik sangat bermanfaat dilakukan pada kondisi tertentu yaitu pada saat tidak diinginkan adanya suatu gerakan.

\section{BAHAN DAN METODE}

Penelitian ini merupakan penelitian eksperimen murni (True Experiment). Rancangan eksperimen yang digunakan adalah The Randomise Post Test Only Control Group Design. Populasi dalam penelitian ini adalah mencit (Mus musculus) yang berada di ruang pemeliharaan hewan coba Fakultas Kedokteran Universitas Airlangga.

Pemilihan sampel dalam penelitian ini, peneliti menetapkan kriteria sebagai berikut: Mencit (Mus musculus) dengan jenis kelamin jantan, sehat, usia 8-12 minggu dan berat badan antara 20-25 gram. Sampel yang digunakan dalam penelitian ini adalah 9 ekor mencit pada tiap kelompok. Jumlah sampel secara keseluruhan pada ketiga kelompok adalah 27 ekor mencit (Mus musculus). Penelitian ini dilakukan pada bulan MaretJuli 2012.
Variabel independen dalam penelitian ini adalah model latihan isometrik, sedangkan variabel dependen adalah kadar glukosa darah mencit (Mus musculus) Diabetes Mellitus setelah diberikan model latihan isometrik. Instrumen yang digunakan untuk mengetahui kadar glukosa darah adalah spectrophotometer. Analisis data dilakukan dengan menggunakan uji statistik One-Sample Kolmogorov-Smirnov Test, Oneway ANOVA dan Least Difference Significant (LSD) dengan derajat kemaknaan $\mathrm{p}<0,05$.

\section{HASIL}

Hasil penelitian menunjukkan bahwa data yang diperoleh berdistribusi normal (lihat tabel 1) dan tidak terdapat perbedaan yang bermakna untuk rerata kadar glukosa darah pada keseluruhan kelompok. Hasil uji statistik dengan menggunakan One Way ANOVA dapat dilihat pada tabel 2. Penelitian ini juga memperoleh hasil bahwa: 1) terdapat perbedaan bermakna pada nilai kadar glukosa darah post test antara kelompok 1 dan kelompok 2; 2) tidak ada perbedaan nilai kadar glukosa darah post test antara kelompok 1 dan kelompok 3; 3) tidak ada perbedaan yang bermakna pada nilai kadar glukosa darah post test antara kelompok 2 dan kelompok 3. Hasil uji statistik dengan menggunakan Least Significant Defference (LSD) dapat dilihat pada tabel tabel 3.

Tabel 1. Hasil observasi berat badan dan kadar glukosa darah post test mencit pada kelompok 1 (normal), kelompok 2 (DM) dan kelompok 3 (DM dan latihan isometrik)

\begin{tabular}{|c|c|c|c|c|c|c|}
\hline \multirow[b]{2}{*}{ No } & \multicolumn{2}{|c|}{ Kelompok 1} & \multicolumn{2}{|c|}{ Kelompok 2} & \multicolumn{2}{|c|}{ Kelompok 3} \\
\hline & $\begin{array}{l}\text { BB mencit } \\
\quad \text { (gram) }\end{array}$ & $\begin{array}{c}\text { Kadar glukosa } \\
\text { darah mencit } \\
(\mathrm{mg} / \mathrm{dl})\end{array}$ & $\begin{array}{l}\text { BB mencit } \\
\text { (gram) }\end{array}$ & $\begin{array}{c}\text { Kadar glukosa } \\
\text { darah mencit } \\
(\mathrm{mg} / \mathrm{dl})\end{array}$ & $\begin{array}{l}\text { BB mencit } \\
\text { (gram) }\end{array}$ & $\begin{array}{c}\text { Kadar glukosa } \\
\text { darah mencit } \\
(\mathrm{mg} / \mathrm{dl})\end{array}$ \\
\hline 1 & 24 & 146,64 & 23 & 335,13 & 22 & 122,00 \\
\hline 2 & 22 & 75,46 & 22 & 204,40 & 21 & 126,95 \\
\hline 3 & 25 & 165,00 & 24 & 120,00 & 21 & 150,67 \\
\hline 4 & 23 & 67,85 & 23 & 111,72 & 25 & 128,74 \\
\hline 5 & 20 & 109,49 & 21 & 391,54 & 23 & 165,45 \\
\hline 6 & 22 & 132,32 & 22 & 155,60 & 22 & 134,11 \\
\hline 7 & 24 & 178,88 & 25 & 141,27 & 21 & 142,17 \\
\hline 8 & 21 & 133,66 & 22 & 548,23 & 26 & 335,13 \\
\hline 9 & 22 & 173,51 & 22 & 201,71 & 23 & 362,88 \\
\hline Uji One-Sample & Rerata $=22,5$ & Rerata $=131,42$ & Rerata $=22,6$ & Rerata $=245,51$ & Rerata $=22,66$ & Rerata $=185,34$ \\
\hline $\begin{array}{l}\text { Kolmogorov- } \\
\text { Smirnov Test }\end{array}$ & $\mathrm{p}=0,89$ & $\mathrm{p}=0,94$ & $\mathrm{p}=0,56$ & $\mathrm{p}=0,50$ & $\mathrm{p}=0,84$ & $\mathrm{p}=0,19$ \\
\hline
\end{tabular}


Tabel 2. Hasil anasilis statistik kadar glukosa darah antara kelompok kelompok 1 (normal), kelompok 2 (DM) dan kelompok 3 (DM dan latihan isometrik) dengan menggunakan One Way ANOVA

\begin{tabular}{cccc}
\hline \multirow{2}{*}{ Keterangan } & \multicolumn{3}{c}{ Kelompok } \\
\cline { 2 - 4 } & $\mathbf{1}$ & $\mathbf{2}$ & $\mathbf{3}$ \\
\hline Rerata (mean) & 131,42 & 245,51 & 185,34 \\
Standar Deviasi & 40,37 & 148.83 & 93.98 \\
Signifikansi (p) & & 0,08 & \\
\hline
\end{tabular}

Tabel 3. Hasil analisis statistik menggunakan Post Hoc Test-LSD

\begin{tabular}{ccccc}
\hline \multicolumn{2}{c}{ Kelompok } & Rerata (I-J) & Signifikansi \\
\cline { 1 - 2 } Kelompok $(\mathbf{I})$ & Kelompok $(\mathbf{J})$ & & .029 \\
\hline Kontrol & DM & $-114.08820^{*}$ & .284 \\
& DM dan latihan & -53.92072 & .029 \\
DM & Kontrol & $114.08820^{*}$ & .233 \\
& DM dan latihan & 60.16748 & .284 \\
DM dan latihan & Kontrol & 53.92072 & .233 \\
& DM & -60.16748 & \\
\hline
\end{tabular}

\section{PEMBAHASAN}

Kadar glukosa darah mencit pada kelompok 1 didapatkan hasil yang bervariasi sebesar 67,85 hingga $178,87 \mathrm{mg} / \mathrm{dl}$. Sampel glukosa darah ini diambil paska pemberian glukosa oral. Dalam penelitian ini kadar glukosa darah pada kelompok 1 dijadikan acuan sebagai kadar glukosa darah normal.

Secara fisiologis setelah pemberian glukosa, kadar glukosa darah meningkat dan mencapai puncaknya pada waktu 1 jam, kemudian turun ke kadar 2 jam. Pada keadaan fisiologis, insulin disekresikan sesuai dengan kebutuhan tubuh normal oleh sel beta. Sekresi insulin normal akan terjadi setelah adanya rangsangan seperti glukosa yang berasal dari makanan atau minuman. Insulin yang dihasilkan berfungsi mengatur regulasi glukosa darah agar selalu dalam batas fisiologis, baik saat puasa maupun setelah mendapat beban. Sekresi insulin berfungsi untuk menjaga kadar glukosa darah selalu dalam batas normal, sebagai cerminan metabolisme glukosa yang fisiologis (Sherwood, 2011). Rendahnya sensitivitas atau tingginya resistensi jaringan tubuh terhadap insulin dapat mempengaruhi metabolisme glukosa pada tubuh. Selain itu regulasi glukosa darah tidak hanya berkaitan dengan metabolisme glukosa di jaringan perifer, tapi juga di jaringan hepar dimana GLUT-2 berfungsi sebagai kendaraan pengangkut glukosa melewati membran sel kedalam sel. Dalam hal ini jaringan hepar ikut berperan dalam mengatur homeostasis glukosa tubuh (Weyer, 2000).

Pada penelitian ini kadar glukosa darah pada kelompok 1 memiliki rentang yang cukup jauh (dilihat dari standar deviasi pada analisis statistik). Peneliti berasumsi bahwa rentang yang cukup jauh pada kadar glukosa darah post test mencit kelompok 1 dapat disebabkan oleh sensitivitas dan resistensi terhadap insulin yang berbeda pada setiap mencit.

Hasil pengukuran kadar glukosa darah pada kelompok 2 didapatkan bahwa 4 ekor mencit berada pada rentang normal yaitu antara 111,72-155,60 mg/dl, sedangkan 5 ekor mencit lainnya pada pengukuran kadar glukosa darah menunjukkan nilai diatas normal yaitu antara 201,71-548,23 mg/dl. Kadar glukosa darah pada kelompok 2 dijadikan acuan sebagai kadar glukosa darah 
paska pemberian glukosa pada mencit yang mengalami Diabetes Mellitus (DM).

Berdasarkan teori dari Szkudelski (2001) disebutkan bahwa streptozotocin (STZ) bekerja dengan menghasilkan Nitrit oxide (NO) dan oksigen reaktif yang merusak pankreas sehingga tidak dapat menghasilkan insulin dengan normal dan menyebabkan kadar glukosa darah tinggi. Dampak STZ sendiri sesuai standar operasional prosedur penyuntikan STZ oleh Animal Models of Diabetic Complications Consortium (2003), akan terllihat pada 2 hari hingga 4 minggu setelah penyuntikan. Pada penelitian ini pengambilan sampel darah dilakukan pada 2x24 jam setelah penyuntikan yang merupakan batas minimal terlihatnya dampak dari STZ.

Pada DM tipe 1 terjadi kerusakan pankreas sehingga tidak dapat atau kurang mampu memproduksi insulin. Ketidakmampuan untuk menghasilkan insulin menyebabkan glukosa menjadi menumpuk di dalam peredaran darah karena tidak dapat diangkut ke dalam sel. Hal ini menyebabkan peningkatan kadar glukosa darah di dalam sel (Smeltzer \& Bare, 2002)

Peneliti berasumsi bahwa kadar glukosa darah pada 4 mencit yang masih berada pada rentang kadar glukosa darah normal dapat disebabkan oleh STZ yang disuntikkan belum memberikan dampak secara maksimal pada hari ke-2. Terdapat peningkatan kadar glukosa yang sangat signifikan pada 3 mencit yang mencapai nilai $353,16 \mathrm{mg} / \mathrm{dl}, 391,54 \mathrm{mg} / \mathrm{dl}$ dan 548,23 $\mathrm{mg} / \mathrm{dl}$ hal ini dapat disebabkan oleh kerusakan pankreas pada mencit akibat suntikan STZ. Kerusakan pankreas yang terjadi menyebabkan produksi insulin berkurang sehingga kadar glukosa darah meningkat. Peneliti berasumsi bahwa perbedaan kadar glukosa darah yang berbeda-beda pada tiap mencit pada kelompok 2 dapat juga dikarenakan faktor genetik dan respons fisiologis tiap mencit yang berbeda-beda dalam beradaptasi terhadap suntikan STZ. Kedua faktor tersebut belum dapat dikendalikan oleh peneliti, sehingga perlu dibuktikan lebih lanjut pengaruh faktor genetik dan respons fisiologis mencit terhadap kadar glukosa darah.

Hasil pengukuran kadar glukosa darah pada kelompok 3 didapatkan bahwa 7 ekor mencit berada pada rentang kadar glukosa darah normal yaitu $122,00-165,45 \mathrm{mg} / \mathrm{dl}$. Hal ini sesuai dengan pendapat Warren (2000) bahwa peningkatan aliran darah ke otot selama latihan dapat meningkatkan distribusi insulin ke otot sehingga memicu masuknya glukosa ke dalam otot pada fase akut. Latihan juga meningkatkan jumlah reseptor insulin dan jumlah aktivitas intrinsik dari glukosa transporter menuju membran plasma sel otot. Dua mencit lainnya pada kelompok 3 memiliki kadar glukosa darah sebesar 335,13 $\mathrm{mg} / \mathrm{dl}$ dan $362,88 \mathrm{mg} / \mathrm{dl}$ yang masih diatas kadar glukosa darah normal. Kondisi ini dapat terjadi dikarenakan adanya kemampuan tubuh dalam menanggapi stres yang diberikan berbeda-beda pada mencit dimana menurut pendapat Sugiharto (2003) disebutkan bahwa latihan fisik sebaiknya dilakukan sesuai dengan kemampuan tubuh dalam menanggapi stres yang diberikan, bila tubuh diberi beban latihan yang terlalu ringan maka tidak akan terjadi proses adaptasi sehingga kadar glukosa darah tidak mengalami penurunan signifikan.

Mekanisme kerja latihan isometrik terhadap penurunan kadar glukosa darah pada Diabetes Mellitus (DM) dimulai ketika penderita DM mengalami resistensi insulin atau defisiensi insulin yang diakibatkan oleh kerusakan sel $\beta$ pankreas. Kekurangan insulin dapat menyebabkan terjadinya sedikit atau tidak ada ikatan dengan reseptor sehingga proses translokasi transporter glukosa 4 (GLUT-4) ke membran sel menjadi terhambat. GLUT-4 memfasilitasi masuknya glukosa ke dalam sel. Bila proses translokasi GLUT-4 terganggu akan menyebabkan ambilan glukosa dalam darah menjadi terganggu, sehingga terjadi penumpukan glukosa di ekstrasel yang akan mengakibatkan glukosa darah meningkat atau disebut juga hiperglikemia (Ganong, 2008).

Salah satu stimulus untuk merangsang translokasi GLUT-4 ke permukaan membran sel adalah melalui kontraksi otot. Penggunaan treadmill tanpa inklinasi, akan menimbulkan suatu kontraksi isometrik. Pada latihan isometrik terjadi suatu kontraksi yang akan menyebabkan retikulum sarkoplasma (SR) melepaskan sejumlah ion kalsium $\left(\mathrm{Ca}^{2+}\right)$ di sitosol. $\mathrm{Ca}^{2+}$ di sitosol akan mengaktifkan enzim Calmodulin Dependent Protein Kinase (CaMK II) yang akan merangsang translokasi GLUT-4 (Guyton \& 
Hall, 2007). Pada latihan isometrik dibutuhkan energi untuk melakukan kontraksi. Kontrakasi otot terus berlangsung menyebabkan peningkatan pemakaian energi sehingga terjadi penurunan Adenosine Triphosphate (ATP). ATP akan dipecah menjadi cyclic Adenosine Monophosphate (cAMP) oleh enzim Adenosine Monophosphate Kinase (AMPK). Enzim CaMK II dan AMPK memiliki fungsi yang sama yaitu mentranslokasi GLUT-4 yang berfungsi memfasilitasi ambilan glukosa masuk ke dalam sel sehingga terjadi penurunan glukosa darah (Rose, 2005).

Latihan fisik yang dilakukan merupakan salah satu bentuk stresor fisik yang dapat menyebabkan gangguan homeostatis, maka tubuh akan memberi tanggapan berupa mekanisme umpan balik negatif (Sugiharto, 2000). Tanggapan tersebut berupa responss 'jawaban sewaktu' adalah perubahan fungsi organ tubuh yang sifatnya sementara dan berlangsung tiba-tiba, sebagai akibat dari aktivitas fisik. Perubahan fungsi ini akan hilang dengan segera dan kembali normal setelah aktivitas dihentikan dalam jangka waktu tertentu. Tanggapan lainnya disebut adaptasi "jawaban lambat" adalah perubahan struktur atau fungsi organorgan tubuh yang sifatnya lebih menetap karena latihan fisik yang dilakukan dengan teratur dalam periode waktu tertentu. Reaksi adaptasi hanya akan timbul apabila beban latihan yang diberikan intensitasnya cukup memadai dan berlangsung cukup lama.

Ada dua istilah latihan yaitu acute exercise (latihan yang bersifat akut) dan chronic exercise (latihan yang bersifat kronik). Acute exercise adalah latihan yang dilakukan hanya sekali saja atau disebut juga dengan exercise, sedangkan chronic exercise adalah latihan yang dilakukan berulang-ulang sampai beberapa hari atau sampai beberapa bulan (training) (Harsono di dalam McArdle, 2001). Hal penting yang perlu diperhatikan ialah dengan melakukan training akan terjadi perubahan penting di dalam tubuh sedangkan dengan melakukan exercise perubahan yang terjadi kurang penting. Perubahan yang terjadi pada waktu seseorang melakukan exercise disebut dengan respons. Sedangkan perubahan yang terjadi karena training disebut adaptasi (Supriadi, 2000). Sebuah latihan yang dilakukan secara akut dapat meningkatkan GLUT4 mRNA pada otot tikus. AMP-activated protein kinase (AMPK) akan aktif dan meningkat diotot rangka pada latihan yang dilakukan secara rutin (Burton, 2004). Berdasarkan pendapat tersebut, maka penelitian ini dilakukan dengan memberikan acute exercise sehingga pendapat tersebut menjelaskan kemungkinan kurang efektifnya exercise pada beberapa mencit.

Berdasarkan hasil analisis statistik dengan Post-Hoc Test dengan LSD didapatkan hasil bahwa tidak terdapat perbedaan yang bermakna antara hasil kadar glukosa darah kelompok 2 dan kelompok 3. Hasil tersebut menunjukkan bahwa mencit DM maupun mencit DM yang diberikan latihan isometrik tidak memiliki perbedaan kadar glukosa darah secara bermakna. Peneliti berasumsi hal ini terjadi dikarenakan oleh pada kelompok 2 masih terdapat kadar glukosa darah normal dan pada kelompok 3 tidak diketahui kadar glukosa darah awal yang mungkin saja memiliki kadar glukosa darah normal. Selain itu dalam penelitian ini latihan isometrik hanya diberikan 1 kali (akut) dan latihan yang diberikan merupakan latihan yang di kondisikan untuk mencit sehingga menimbulkan stres fisiologis yang dapat menjadi sumber peningkatan kadar glukosa darah.

\section{SIMPULAN \& SARAN}

\section{Simpulan}

Berdasarkan hasil penelitian dapat disimpulkan bahwa pemberian model latihan isometrik tidak dapat menurukan kadar glukosa darah pada mencit Diabetes Mellitus

\section{Saran}

Peneliti menyarankan agar dilakukan penelitian lanjutan dengan menggunakan desain penelitian pre-post control group design untuk mengetahui kadar glukosa darah awal sebelum dan sesudah perlakuan sehingga peneliti mengetahui nilai perubahan kadar glukosa darah. Paska injeksi Streptozotocin (STZ) dikontrol sampai waktu maksimal agar mencit menjadi DM dan sebelum diberi perlakuan sebaiknya kadar glukosa darah mencit diukur terlebih dahulu untuk mengetahui kadar glukosa darah pasca penyuntikan Streptozotocin. Frekuensi dan intensitas latihan isometrik sebaiknya 
ditambah untuk melihat efek latihan terhadap kadar glukosa darah.

\section{KEPUSTAKAAN}

American Diabates Association 2010, Clinical Practice Recommendations. Diabetes Care. http://care.diabetesjournals.org. Diakses tanggal 15 Mei 2012 pukul 12.30 WIB.

American Diabates Association 2011, Diagnosis and Classification of Diabetes Mellitus, Diabetes Care. http://care.diabetesjournals.org. Diakses tanggal 30 April 2012 pukul 10.05 WIB.

DeFronzo, RA 2010, Pathogenesis of Type 2 Diabetes: Metabolic and Molecular Implications For Identifying Diabetes Genes. Diabetes Review. Hal. 177-269.

Indriyani, P., Supriyanto, H \& Santoso, A 2007, Pengaruh Latihan Fisik: Senam Aerobik Terhadap Penurunan Kadar Gula Darah pada Penderita DM Tipe 2 di Wilayah Puskesmas Bukateja Purbalingga $<$ http://ejournal.undip.ac.id/index.ph p/medianers/article/view/717> diakses 13 Maret 2012.

Nadimin, AS, Sadariah 2009, Pengaruh Pemberian Diit DM Tinggi Serat Terhadap Penurunan Kadar Glukosa Darah Pasien DM Tipe-2 Di RSUD Sawelangan Kabupaten Maros, Media Gizi Pangan, Vol. VII, Edisi 1 ,

https://jurnalmediagizipangan.files. wordpress.com, diakses 15 April 2012.

PERKENI 2011, Konsensus Pengelolaan Diabetes Mellitus Tipe 2 di Indonesia, Jakarta.
Rose, AJ \& Richter, EA 2005, Skeletal Muscle Glukosa Uptake During Exercise: How is it Regulated?, Physiology, Vol. 20, Hal. 260-270, http://physiologyonline.physiology.o rg/content/20/4/260.full.html\#reflist-1, diakses 20 Maret 2012.

Szkudelski, T 2001, The Mechanism Of Alloxan And Streptozotocin Action In $\beta$ Cells of The Rat Pancreas, Physiology Research, Hal. 536-54.

Siegel, K \& Narayan, KMV 2008, The Unite for Diabetes campaign: Overcoming constraints to Find a Global Policy Solution, BioMed Central, 19 Februari, Globalization and Health, <http://www.biomedcentral.com/con tent/pdf/1744-8603-4-3.pdf>, diakses 20 Maret 2012.

Sigal, RJ, Kenny, GP, Wasserman, DH \& Sceppa, CC 2004, Physical activity/ Exercise and Type 2 Diabetes, Diabetes Care, Vol. 27, No. 10, Hal. 2518-2539,

<http://care.diabetesjournals.org/co ntent/27/10/2518.full>, diakses 12 Maret 2012.

Weyer C, Bogardus C, Mort DM, Tataranni PA, Pratley RE 2000. Insulin resistance and insulin secretory dysfunction are independent predictors of worsening of glucose tolerance during each stage of type 2 diabetes development. Diabetes Care, Vo. 24, Hal. 89

Wood, IS, Trayhurn,P 2003, Glucose Transporters (GLUT and SGLT): Expanded Families of Sugar Transport Proteins, British Journal of Nutrition, Vol. 89, Hal. 3-9. 